\title{
Geografija nemjesta: analiza Arena Centra u Zagrebu (mikrorazina)
}

\author{
Karlo Mak \\ Gimnazija Antuna Gustava Matoša, Samobor, Hrvatska \\ e-mail:karlo.mak2@skole.hr
}

\author{
Martina Jakovčić \\ Prirodoslovno-matematički fakultet Sveučilišta u Zagrebu, \\ Geografski odsjek, Hrvatska \\ e-mail:mjakovci@geog.pmf.hr
}

SAŽETAK Naslanjanjem na Augéov koncept nemjesta osmišljen je interpretativni model analize trgovačkog centra. Pritom su koncipirane dvije dijalektički povezane razine. Za potrebe analize na nižoj prostornoj razini (Arena Centar) koncept nemjesta fuzioniran je sa Schatzkijevim konceptom društvenog prizorišta, dok se makrorazina (naselja oko Arena Centra) temelji na markerima tranzitnosti koje posjetitelji centra ostavljaju u prostoru. Ovaj rad donosi rezultate istraživanja na nižoj prostornoj razini. Operacionalizacijom osmišljenog modela utvrđeno je da se, uslijed prostornog preobilja i prekomjernosti značenja, predodžbe posjetitelja centra ne podudaraju s idejnim rješenjem gradnje. Dokazano je kako posjetitelji to više gube dodir $s$ eksternom prostorno-vremenskom realnošću što više vremena provedu u centru. Konačno, potvrđeno je postojanje dinamike različitih potrošačkih praksi zbog kojih prostor Arena Centra nije isključivo trgovinski, već i prostor aktivnosti za provođenja slobodnog vremena.

Ključne riječi: nemjesto, društveno prizorišste, trgovački centar, Arena Centar.

Copyright (C) 2020 Institut za društvena istraživanja u Zagrebu - Institute for Social Research in Zagreb Sva prava pridržana - All rights reserved 


\section{Uvod}

"Svijet supermoderniteta [koji stvara nemjesta] nije na vlas podudaran svijetu u kojem mislimo da živimo, jer živimo u svijetu koji još nismo naučili gledati. Moramo iznova naučiti promišljati prostor". Intencija Augéovog narativa o ubrzanju povijesti, sažimanju prostora (prostorno-vremenska konvergencija), porastu mobilnosti, sve većoj povezanosti svijeta, demontiranju dosadašnje koncepcije vremena, prostora i individualnosti jest pridobiti pažnju autora koji se bave prostornim i njima bliskim pitanjima, gradeći postmodernistički koncept nemjesta (Augé, 2001.:36; Merriman, 2004.).

Predmet bavljenja ovog rada je Arena Centar, trenutno najveći trgovački centar u Zagrebu i jedan od pojavnih oblika nemjesta. Trgovački centri pojavljuju se u Hrvatskoj tek polovicom 1990-ih godina, no do danas su se izvanredno prostorno proširili.

Cilj istraživanja bio je osmisliti model koji s aspekta ekonomske geografije nudi analizu trgovačkog centra kao dinamično-tranzitnog prostora. $U$ ovom radu donosimo isključivo rezultate dobivene na nižoj prostornoj razini (razina samog trgovačkog centra). Ona podrazumijeva razmatranje stvaranja trgovinskog prostora uvidom u potrošačke prakse posjetitelja centra, odnosno određivanje stupnja do kojeg se kroz potrošačke aktivnosti i predodžbe realiziralo idejno rješenje gradnje Arena Centra. Rad provjerava dokle seže odvojenost posjetitelja centra od izvanjske vremenske i prostorne realnosti, a sve sa svrhom dobivanja informacije funkcionira li Arena Centar uistinu kao nemjesto. Pritom se polazi od teze da je trgovački centar hibridni oblik na relaciji između mjesta i nemjesta te da ako se za to steknu uvjeti - u pogledu odgovarajuće dinamike i određenog intenziteta tranzitnosti - može poslužiti kao generator bezmjesnosti.

Polazne hipoteze u istraživanju bile su: I. predodžbe posjetitelja Arena Centra o tom trgovinskom prostoru ne podudaraju se $s$ idejnim arhitektonskim rješenjem gradnje; II. za vrijeme boravka u trgovačkom centru posjetitelji gube dodir s (eksternom) prostornom i vremenskom realnošću; III: u trgovačkom se centru odvija dinamika različitih potrošačkih praksi kojom se stvara potrošački prostor, a razlikuje se ovisno o dijelu tjedna, odnosno dana; IV: broj i koloplet potrošačkih praksi mijenjaju se s trajanjem boravka u centru.

Arena Centar izabran je kao prostor istraživanja budući da je on primjer centra koji bi, prema Colemanu (2006.), ulazio u skupinu centara planiranih kao sastavnih dijelova sasvim novog grada, konkretno gradske četvrti Novi Zagreb - zapad. Iako je Lanište naselje koje je postojalo i ranije, $s$ najavom gradnje višenamjenske sportske dvorane i trgovačkog centra dolazi do novog zamaha u izgradnji. Idejnim se rješenjem predviđala gradnja sportske dvorane i trgovačkog centra kao cjeline, pri čemu bi se parkirališni prostor koristio kao zajednički. Cijeli je kompleks građen s ciljem da postane jezgra novog središta okupljanja u jugozapadnom dijelu grada te se procjenjivalo da će kao takav zaživjeti u roku od deset godina (Nodilo, 2010.). Unutrašnjost Arena Centra 
arhitektonski je osmišljen s intencijom da oslikava geografsku strukturu Hrvatske (Ciglar i Opalić, 2010.). Kako se u trgovinske prostore nerijetko inkorporiraju predodžbe različitih prostornih toponima (Šakaja, 2015.), tako su trgovi Arena Centra projektirani kao posebni kružni prostori nazvani po hrvatskim regijama: Istri, Dalmaciji i Slavoniji. Prilagodba trgovačkog prostora lokalnim (nacionalnim) uvjetima, o čemu je raspravljala Stanić (2009.), ovdje je ostvarena odabirom odgovarajuće teme, odnosno integriranim unutrašnjim konceptom centra, čija bi se cjelovitost trebala ostvariti asocijacijama na pulsku arenu (Istra), jedrenjake (Dalmacija) i izduženost (Slavonija) kao univerzalno razumljive prostorne označitelje.

Aktivnosti posjetitelja trgovačkog centra prije svega ovise o njegovoj ponudi. Budući da trgovina na malo zauzima čak 81,3 \% svih zakupljenih prostora Arena Centra, može se očekivati da će glavna aktivnost biti kupovanje. Ugostiteljski objekti nalaze se u 9,4 \%, usluge u 7,4 \%, a zabavišni objekti u tek 2,0 \% zakupljenih prostora (Arena Centar, 2019.). Međutim, te brojke sakrivaju podatak o površini zakupljenih objekata. Na primjer, samo prostor CineStar kina zauzima 9,7 \% površine centra (CineStar, 2019.; Arena centar, 2017.). Zbog nepostojanja javno dostupnih podataka o površini ostalih prodajnih prostora, valja tek pretpostaviti da će dominirati aktivnost kupovine, a da će odlazak u kino biti razlogom dolaska za oko desetinu posjetitelja centra.

\section{Teorijski okvir istraživanja}

Istraživanje trgovačkih centara postaje akademski relevantno tek u razdoblju tercijarizacije društva. Među geografima koji su dali značajniji obol toj temi svakako su Lukić (2002.), Lukić i Jakovčić (2004.), Jakovčić i Spevec (2004.) te Jakovčić i Rendulić (2008.). Baviti se temama vezanim uz potrošnju ranije značilo je pozicionirati se na margine akademskog ugleda (Crewe, 2000.). Znanstvena proučavanja trgovačkih centara uglavnom su se usmjeravala na sadržaje centara, ulogu sidrenih objekata i specifična obilježja posjetitelja (Jakovčić, 2011.). Baveći se historijskim razvojem prostora potrošnje, Coleman (2006.) je značajan dio rada posvetio trgovačkim centrima, njihovim obilježjima, prostornom širenju i suvremenim problemima. Goss (1993.) do srži dekonstruira prostor trgovačkog centra ukazujući na odnose moći koji njime upravljaju, utilitarnost sadržaja i ugođaja. Woodward (1998.) uzima trgovački centar kao egzemplar postmodernog prostora, a Makgopa (2016.) analizira koje atribute posjetitelji centara razmatraju kad odlučuju koji će trgovački centar posjetiti. Bloch i sur. (1994.) ispitivali su potrošačke aktivnosti unutar trgovačkog centra. Lourenco i Bardi (2007.) proučavaju odnos između propadanja tradicionalnih trgovinskih četvrti u središtima i uspona trgovačkih centara na rubovima gradova, a Szczuraszek i Karwasz (2018.) izrađuju analitički model za ispitivanje količine cestovnog prometa koji generiraju trgovački centri. 
Određen broj radova u Hrvatskoj također problematizira trgovačke centre, poglavito njihove funkcije. Tako Tonković (2015.b) ispituje zastupljenost kupaca hedonista i kupaca utilitarista, ali i socijalne funkcije trgovačkog centra. Odnosom trgovinskih i netrgovinskih funkcija bave se i Lukić (2002.), Jakovčić i Spevec (2004.), Lukić i Jakovčić (2004.), Jakovčić i Rendulić (2008.) te Stanić (2009.). Anić, Dlačić i Jelenc (2016.) istražuju pojavu kompulzivne kupovine u trgovačkim centrima te utvrđuju njezinu povezanost sa sklonošću prema hedonizmu i raznolikošću prodajnih objekata unutar centra. Mak, Dumić i Jakovčić (2017.) istražuju potrošačke navike mladih, među ostalim i u okviru trgovačkih centara, a Mak i Knežević (2017.) ispituju može li trgovački centar funkcionirati kao mjesto okupljanja ruralne populacije. Inače, geografska istraživanja trgovine u Hrvatskoj moguće je pratiti tek od 2002. godine (Jakovčić i Rendulić, 2008.). Tada je Lukić (2002.) razradio tipologiju prodajnih centara te detektirao izraženost socijalne funkcije Centra Kaptol naspram trgovinskoj. Bavljenje trgovačkim centrima u Hrvatskoj uključivalo je i proučavanje njihove prostorne distribucije (Jakovčić i Spevec 2004.; Lukić i Jakovčić, 2004.), odnosno veze između suburbanizacije trgovine i popratnih procesa u gradskim središtima (Tonković, 2015.a).

\subsection{Istraživački pristup i koncept nemjesta}

Paradigma prostornog obrata odabrana je kao istraživački pristup u ovome radu. Odražavajući nejednak razvoj historijskog nasuprot prostornom diskursu, prostorni je obrat prije svega pokušaj da se razvije kreativnija i kritički djelotvornija ravnoteža između prostornih (geografskih) i vremenskih (historijskih) imaginacija (Soja, 2008.). Dok se o vremenu u razdoblju moderne mislilo dinamički, dotle se prostor smatralo fiksnim, mrtvim i nepokretnim, drugim riječima kontejnerom za društvene procese i povijest (Foucault, 1997.). Prostor je imao striktno geometrijsko značenje te mu se u pravilu pristupalo deskriptivno (Lefebvre, 1991.). S druge strane, zagovaratelji prostornog obrata ističu da prostor nije kontejner (Arias, 2008.). Stoga kao teorijski okvir ovoga rada razmatramo postmodernizam. Dok je modernizam bio zakačen za istinu, a istina - u onoj mjeri u kojoj uopće postoji - je prije svega ovisna o predodžbi promatrača, postmodernizam je svjestan da postoji mnogo istina i ostaje im otvoren. Time je kao odabrani teorijski okvir on inherentno geografski u smislu svoje osjetljivosti na različito i na diferencijaciju, na prostor i tempo te na prostornost i dinamičnost, više nego što je modernistička geografija ikad bila (Soja i Hooper, 1993., prema Clarke, 2006.).

Koncept unutar paradigme prostornog obrata koji će biti implementiran u prostornu analizu Arena Centra već je spomenuta Augéova koncepcija nemjesta. Nemjesto je "prostor koji ne možemo odrediti ni kao identitaran, ni kao odnosni, ni kao povije- 
stan" (Augé, 2001.:75). "Pojedinac ne stvara vezu s nemjestom jer nemjesta karakterizira odsutnost značenja” (Ursić, 2009.:1145). U njima "nema mjesta za povijest: u najboljem se slučaju [povijest] pretvara u element prizora, najčešće u nagovještajne tekstove" (Augé, 2001.:94). ${ }^{2}$ Navest ćemo samo neke primjere - zračni, željeznički i cestovni pravci, prometna sredstva, kolodvori, zračne luke, hotelski lanci, supermarketi, robne kuće, trgovački centri, multipleksi, tematski parkovi, turističke lokacije, telekomunikacijska mreža i dr. (Gregory i sur., 2009.; Sibley i sur. 2005.). Kako bi se nemjesta mogla formirati, potrebno je zadovoljiti "tri figure prekomjernosti" kojima se određuje stanje supermoderniteta - vremensko (događajno) preobilje (franc. surabondance événementielle, engl. factual overabundance), prostorno preobilje (franc. surabondance spatiale, engl. spatial overabundance) te individualizacija referencija (franc. individualisation des références, engl. self-reflexive individuality) (Augé, 2001.:40). Događajno preobilje izravno utječe na svojevrsnu akceleraciju povijesti, a to onda dovodi i do "ubrzanja transformacije prostora" (Ursić, 2009.:1140). ${ }^{3}$ Ipak, geografiji je najzanimljivije prostorno preobilje, koje se "očituje u promjenama mjerila, u množenju slikovnih i zamišljajnih referencija [TV, internet, reklame] i spektakularnom ubrzanju prometnih sredstava” (Augé, 2001.:35). Istodobno, dovodi do toga da čovjek sve manje razumije prostor, a sve mu više želi pripisati značenje (Varnelis, 2010.). Prostorno preobilje stvara ogromne morfološke, funkcionalne i socijalne promjene, utječe na urbanu koncentraciju, prostorni razmještaj stanovništva te, konačno, na stvaranje nemjesta.

Nadalje, "neka mjesta postoje samo zahvaljujući riječima koje ih oživljavaju i u tom su smislu nemjesta” (Augé, 2001.:87). Njihov naziv stvara određen mit koji istovremeno formira njihovu lokaciju. Suprotno tomu, "zbiljska nemjesta supermoderniteta” kojima pojedinac prolazi vozeći se autocestom ili za vrijeme kupovine u trgovačkom centru specifična su "utoliko što ih određuju i riječi ili tekstovi koje nam nude", primjerice prometna signalizacija, znaci zabrane ili drugi alati informiranja (Augé, 2001.:88).

1 S druge strane, antropološka mjesta imaju bar tri zajednička obilježja - indentitarnost, odnosnost i povijesnost. Međutim, treba naglasiti da nemjesto nije negacija mjesta, već je s njime dijalektički povezano (Gregory i sur., 2009.). Iako u svojevrsnoj opreci, mjesta i nemjesta ne egzistiraju odvojeno i bez međusobnih upliva, već se u "konkretnoj stvarnosti današnjeg svijeta [...] prepliću i prožimaju" (Augé, 2001.:97). Ili kako je to francuski antropolog formulirao prilikom predstavljanja svog kapitalnog djela u Tallinnu 2012. godine - ne postoje u potpunosti distinktivna mjesta ili nemjesta - ono što nekome predstavlja mjesto, drugome može biti nemjesto, i obrnuto (Laviolette, 2012.).

2 Primjerice, trgovački centar Roses Designer Outlet u Svetom Križu Začretju građen je po uzoru na baroknu jezgru Varaždina, dok su na glavnom ulazu u centar smješteni antički stupovi s trijemom. Drugim riječima, povijest je ovdje pretočena u arhitektonsku izvedbu trgovačkog centra.

${ }^{3}$ Naime, odvijanjem malog broja događaja stvara se dojam sporosti. S druge strane, povećanjem broja događaja postiže se dinamika, a to nužno rezultira i prostornim promjenama. 
Međutim, nemjesta su u mnogočemu sama sebi proturječan koncept. Tako su ipak obilježena i određenom svrhovitošću (prijevoz, trgovinska aktivnost, slobodno vrijeme) te odnosom koji pojedinac s njima stvara (Augé, 2001.). Malo je kritičke pozornosti usmjereno na Augéov pokušaj da teoretizira kako je stanje supermodernosti konkretizirano, posredovano ili doživljeno u sklopu onoga što naziva nemjestima. Merriman (2004.) se tako osvrće na Augéov istraživački postupak ističući da je prepun kontradiktornosti, počevši od toga da tvrdi kako ljudska bića ne raspoznaju da se nalaze u nemjestima, dok ih istovremeno Augé, kao antropolog (i čovjek), može spoznati i analizirati. Dio ga autora kritizira zbog činjenice da ne prepoznaje kako pojedinci kao što su radnici, zaštitari, kupci/potrošači ili putnici često doživljavaju prostore kao što su supermarketi, autoceste ili zračne luke kao mjesta u čitavom njihovom antropološkom bogatstvu (Menatti, 2011.; Tomlinson, 1999.). Prema tomu, postaje važno razmišljati o različitim položajima (perspektivama) korisnika nemjesta (Merriman, 2004.; Tomlinson, 1999.). Osim toga, prihvatimo li određenje trgovačkih centara kao "mjesta na kojima je kupovina izraz prestiža, moći i simbolizma znatno više nego jednostavne ekonomske potrebe" (Zlatar, 2011.:319), onda oni zasigurno ne mogu biti promatrani isključivo kao nemjesta. Ovisno o kutu gledanja, upitno može biti i osnovno određenje nemjesta kao prostora koji nije ni identitaran, ni relacijski ni povijestan. Naime, ako se prostor stvara, ako postoji proces stvaranja, tada nužno govorimo o povijesti (Lefebvre, 1991.). Različito značenje može stvarati i putovanje zrakoplovom s obzirom na to putuje li se ekonomskom, poslovnom ili prvom klasom. Također, nije isto koristi li se vozač na autocesti posve novim ili pak starim, polovnim automobilom. Pa čak i u slučaju da vozači rabe u potpunosti jednake automobile, razliku mogu stvarati registracijske oznake. Međutim, ono što ostaje neupitno jest činjenica da su nemjesta prije svega tranzitni prostori - prostori koji služe kako bi se došlo do nekog mjesta ili realizirala neka uobičajena ljudska praksa (Ursić, 2009.). Prema tomu, "putnikov bi prostor [...] bio arhetip nemjesta" (Augé, 2001.:81). Svijet nemjesta svijet je brzine, heterogenosti i protoka ljudi i dobara (Sibley i sur., 2005.). Naposljetku, ključni moment u definiranju nemjesta bila bi njihova tranzitnost i dinamika koja se time stvara. Nemjesta su prije svega prostori kroz koje prolazimo (Gregory, 2011.).

Koncept nemjesta danas je u mnogočemu zastario i teško može biti aplikativan u svrhu prostorne analize. Stoga ga i sam Augé počinje shvaćati kao metaforu mnogo korisniju kao misaonu nego li analitičku kategoriju (Laviolette, 2012.). Ipak, kako bi koncept bio istraživački aplikativan, nužno je pristupiti njegovom redefiniranju. Razmatrajući nedostatke klasičnog poimanja nemjesta, uočili smo obilježja koja ostaju neupitna - tranzitnost i dinamiku - ključna obilježja na osnovu kojih valja prosuđivati o nemjesnosti. Sve ostale, izvorne karakteristike koncepta mogu, ali i ne moraju postojati, jednako kao i atributi antropološkog mjesta (povijesnost, identitarnost i odnosnost), pri čemu valja istaknuti kontingentnost, tj. slučajnost i nepredvidljivost njihove pojave. 


\subsection{Primjena koncepta nemjesta na mikro-razini}

Za potrebe konstruiranja modela analize trgovačkog centra na mikrorazini redefinirani koncept nemjesta bit će udružen s konceptom društvenog prizorišta (engl. the social site) Theodorea Schatzkog. Društveno prizorište čine prostorno razmješteni entiteti i društvene prakse. Entiteti obuhvaćaju ljude, artefakte (nastali kao rezultat ljudskog rada), ostale žive organizme te stvari (nastale neovisno o ljudskom djelovanju), dok se pojam društvenih praksi odnosi na organizirane aktivnosti (Schatzki, 2002.). Prakse (i prostorni razmještaji) imaju izuzetno važnu analitičku ulogu s obzirom na to da mogu detektirati kompleksnost, kontingenciju, identitete i značenje inherentne bilo kojem obliku (ekonomske) organizacije (Jones i Murphy, 2011.). Društvena prizorišta karakterizira neprekinuto kretanje/događanje, kontinuirana promjena razmještaja i (re) organizacija njihovih entiteta (Schatzki, 2002.). Schatzkijeva je koncepcija prostora prije svega relacijska. Jedan od temeljnih ishoda razmišljanja o prostoru u takvoj formi jest apostrofiranje kontingencije i neprekidnog procesa prostorne (re)produkcije, odnosno prokazivanje fiksne i statične prostorne forme kao irelevantne (Hui i Walker, 2018.). Time se Schatzkijev koncept društvenog prizorišta izuzetno približava ranije rekonceptualiziranom shvaćanju nemjesta, što čini izuzetno dobro polazište za njihovo funkcionalno povezivanje.

Dinamiku i tranzitnost kao ključna obilježja nemjesta valja uzeti kao temelj analize trgovačkog centra. Kako bi se ona mogla operacionalizirati, dodaju se prostorni akteri i njihov razmještaj, pri čemu je naglasak na odvijanju ljudskih praksi - jer prakse su same po sebi dinamične kao rezultat njihove unutarnje logike (Warde, 2005.) - i njihovoj međusobnoj povezanosti. Kao ishod dobiva se dinamična i neujednačena mreža prostornih tokova, kojom se kontinuirano iznova oblikuje prostor trgovačkog centra. Drugim riječima, Arena Centar promatran je kao mreža koja se konstituira obavljanjem različitih aktivnosti potrošača, a koja je promjenjiva s obzirom na dio tjedna i doba dana, dakle dinamična s obzirom na tranzitnost u odabranom vremenskom odsječku. Drugo, u obzir su uzeta tri trga unutar centra te su uspoređivani njihova idejna rješenja, predodžbe i prakse te stavovi posjetitelja o imenovanju tih prostora prema hrvatskim regijama (tema centra). I konačno, modelom se ispituje povezanost trgovačkog centra $s$ vanjskim prostorom $s$ aspekta odvojenosti od njegovog realiteta kao jedne od ključnih karakteristika nemjesta.

\section{Metodologija istraživanja}

Pri izradi ovog rada korišteno je nekoliko različitih istraživačkih metoda. Značajan dio podataka prikupljen je terenskim istraživanjem, metodom promatranja i metodom anketiranja. Popisani su i klasificirani prodajni, uslužni, zabavišni i drugi objekti te su fotografirani prostori trgova unutar Arena Centra. Središnji dio istraživanja čini anketno istraživanje posjetitelja trgovačkog centra Arena. Pri tome je korišteno probabilističko (sustavno) slučajno uzorkovanje. Uvidom u promjene obrazaca potrošačkog ponašanja s obzirom na dio tjedna, odnosno doba dana (Jakovčić i Rendulić, 2008.), 
odlučeno je anketiranje provesti tijekom triju dana - u utorak (7. svibnja 2019.), četvrtak (9. svibnja 2019.) i u subotu (11. svibnja 2019.) - odnosno u trima terminima - između 10:00 i 12:00 sati, zatim između 14:00 i 16:00 sati te na kraju između 18:00 i 20:00 sati. Pristupilo se svakom n-tom posjetitelju centra $(n=5)$ koji je prolazio pojedinim trgom u unaprijed određeno vrijeme.

Anketni upitnik sastojao se od svega 15 pitanja, na temelju kojih je dobiven uvid u sociodemografski profil ispitanika, učestalost i načine dolaska u trgovački centar, aktivnosti koje posjetitelji u njemu obavljaju te način na koji percipiraju i doživljavaju trgovinski prostor.

Dobiveni rezultati analizirani su pomoću programskog paketa SPSS i MS Excela. Hipoteze su testirane kvalitativno i kvantitativno. Za dobivene podatke koji se tiču predodžbi posjetitelja o pojedinim trgovima unutar Arena Centra provedena je kvalitativna analiza, u okviru koje su kategorizirane dobivene informacije. Metodama deskriptivne statistike, hi-kvadrat testom te izračunavanjem korelacije (Kendallıs tau-b) testirane su preostale hipoteze.

\section{Rezultati i rasprava}

Tijekom triju dana provođenja anketnog istraživanja ukupno se pristupilo 763 posjetiteljima Arena Centra. Od toga je 402 (52,69 \%) pristalo ispuniti anketni upitnik. Valjane su bile 374 ankete s obzirom na to da su 23 (3,01\%) osobe odbijene zbog maloljetnosti, a $5(0,66 \%)$ smo se morali zahvaliti budući da su bili djelatnici centra. Pri obradi podataka odbačena su još $3(0,39 \%)$ ispunjena upitnika koja su ocijenjena nepouzdanima. Stoga se konačni uzorak sastoji od 371 osobe, ili 48,62 \% svih kojima se pristupilo (tablica 1.).

Tablica 1.

Dobno-spolna struktura uzorka

\begin{tabular}{|l|c|c|c|c|c|c|}
\hline Dob & \multicolumn{2}{|c|}{ Ukupno } & \multicolumn{2}{c|}{ Muški } & \multicolumn{2}{c|}{ Ženski } \\
\hline Godina & $\mathrm{N}$ & $\%$ & $\mathrm{~N}$ & $\%$ & $\mathrm{~N}$ & $\%$ \\
\hline $\mathbf{1 8}-\mathbf{2 0}$ & 58 & 15,6 & 17 & 4,6 & 41 & 11,1 \\
\hline $\mathbf{2 0}-\mathbf{2 5}$ & 112 & 30,2 & 50 & 13,5 & 62 & 16,7 \\
\hline $\mathbf{2 5}-\mathbf{3 0}$ & 62 & 16,7 & 32 & 8,6 & 30 & 8,1 \\
\hline $\mathbf{3 0}-\mathbf{4 0}$ & 56 & 15,1 & 27 & 7,3 & 29 & 7,8 \\
\hline $\mathbf{4 0}-\mathbf{5 0}$ & 46 & 12,4 & 16 & 4,3 & 30 & 8,1 \\
\hline$\geq \mathbf{5 0}$ & 34 & 9,2 & 15 & 4,0 & 19 & 5,1 \\
\hline N. $\mathbf{0 .}$ & 3 & 0,8 & 1 & 0,3 & 2 & 0,5 \\
\hline Ukupno & 371 & 100,00 & 158 & 42,59 & 213 & 57,41 \\
\hline
\end{tabular}

Izvor: Anketno istraživanje. 
Kad je riječ o boravištu posjetitelja Arena centra, može se tvrditi da oni dolaze iz gotovo cijele Hrvatske. Pritom je uvjerljivo najveći udio ispitanika bio iz Grada Zagreba (58,2 \%). Slijede Zagrebačka, Karlovačka i Krapinsko-zagorska županija. Osim toga, troje $(0,8 \%)$ ispitanika došlo je iz Slovenije, a osmero (2,2 \%) iz Bosne i Hercegovine. ${ }^{4}$ Medijalna udaljenost mjesta stanovanja posjetitelja do Arena Centra iznosi 12,9 kilometara. Stoga ne treba čuditi da je najveći udio među posjetiteljima zabilježila zagrebačka gradska četvrt Novi Zagreb - zapad.

\subsection{Prepoznatljivost koncepta uređenja centra}

Implementacija osmišljenog konceptualnog modela analize trgovačkog centra polazi od interpretativne analize realizacije teme tog trgovinskog prostora. Zanima nas kako i u kojoj mjeri funkcioniraju predodžbe posjetitelja centra te uspijevaju li posjetitelji identificirati koje hrvatske regije trgovi Arena Centra reprezentiraju.

Zakrivljeni lukovi, koji bi na trgu Dalmacija trebali asocirati na jedrenjake, toliko su apstraktno izvedeni da nije odveć izgledno kako će ih posjetitelji na taj način percipirati. Prostorom trga dominira bijela boja, dok se s padanjem mraka pale neupadljiva plava svjetla. Kombinacijom bijelih i plavih pločica obložen je pod u prizemlju, gdje se smjestio ugostiteljski objekt. U podnožju pokretnih stepenica semiotički je obilježena površina koja bi trebala upućivati na prostor koji taj dio centra reprezentira. Na sličan je način označen zid neposredno ispred ulaza na trg s glavne šetnice na prvome katu. Reprezentacija Istre kudikamo je konkretnije izvedena. Naime, bočni nosači koji su osmišljeni s ciljem da podsjećaju na antički amfiteatar u Puli uistinu su se približili toj svrsi. Prostorom trga dominira bijela boja sa sivim tonovima na stupovima, odnosno crnim pločicama kojima je obložen pod u prizemlju. Baš kao u Dalmaciji, i u prizemlju je Istre smješten ugostiteljski objekt te je na jednak način prostor semiotički obilježen. Središnji trg Arena Centra, s obzirom na svoju izduženost, imenovan je Slavonijom (Nodilo, 2010.). Osim što pruža specifičnu gastronomsku ponudu te izuzev prevladavajućih boja, malo što drugo bi se moglo povezati s tom hrvatskom regijom (uostalom, dobrim dijelom otpada i gastronomski sadržaj budući da ga je gotovo nemoguće povezati sa Slavonijom). Smeđi tonovi pločica te nešto tamnija nijansa stupova koji povezuju tlo sa zlatno-žutim stropom potencijalno ostavljaju dojam zemljane površine i žitnih polja. Sama ponuda trga usmjerena na gastronomsku ponudu u kojoj prevladavaju globalizirani lanci brze prehrane ne nudi mogućnost povezivanja s predviđenim regionalnim konceptom. Trg Slavonija semiotički je obilježen isključivo na prvome katu, ali kako sa zapadnog, tako i s istočnog prilaza.

${ }^{4}$ Budući da ti ispitanici žive uz samu granicu s Hrvatskom (Brežice u Sloveniji, tj. Mostar, Novi Grad, Posušje i Prijedor u $\mathrm{BiH}$ ) te je utvrđeno da poznaju hrvatske regije, opravdano su pridodani ukupnom uzorku. 
Više od dvije trećine $(68,6$ \%) ispitanika koji su anketirani na trgu Dalmacija nije taj prostor moglo povezati ni sa kojom hrvatskom regijom. Od ispitanika koji su pokušali detektirati o kojoj se regiji radi, podjednak je udio istaknuo da je riječ o Dalmaciji i Istri $(10,7 \%) .{ }^{5}$ Ostale su regije bile osjetno manje zastupljene. Potpuno očekivano, čak ni nakon što su upoznati s imenom, nitko od ispitanika nije ponudio objašnjenje imenovanja trga Dalmacija koje bi korespondiralo s izvornom arhitektonskom idejom. Njihova su se tumačenja uglavnom ticala prevladavajućih boja i položaja trga u trgovačkom centru.

Slično kao u slučaju trga Dalmacija, dvotrećinska većina ispitanika (71,0 \%) nije povezala prostor trga Istra ni sa kojom hrvatskom regijom. Međutim, ispitanici koje je taj trg ipak asocirao na neko područje u 17,6 \% slučajeva odlučili su se upravo za Istru. ${ }^{6}$ Razlozi kojima su ispitanici pokušali protumačiti imenovanje trga Istrom u najvećem su se broju slučajeva ticali prostornog identiteta istarskog poluotoka, pri čemu je gotovo četvrtinu ispitanika trg asocirao na pulsku arenu.

Relativno najviše asocijacija na hrvatske regije ponudili su posjetitelji ispitani na trgu Slavonija. Doduše, ni ovdje apsolutna većina (65,6 \%) nije mogla povezati trg ni sa kojim prostorom, no taj je udio u ovom slučaju manji od udjela dobivenih na ostalim trgovima. Da prostor u kojem su ispitivani reprezentira Slavoniju, tvrdilo je $11,8 \%$ posjetitelja ${ }^{7}$, za Istru se odlučilo njih 5,9\%, dok treće mjesto dijele Dalmacija i Hrvatsko zagorje. Čak 55,4 \% posjetitelja tumačilo je kako su ugostiteljska ponuda i s njom povezane aktivnosti koje taj dio centra nudi ključan faktor imenovanja trga Slavonijom. Time se pokazalo da su sociokonstruktivistički čimbenici prevladavali u prostornim predodžbama ispitanika. Svoj je argument u prostranosti i zaravnjenosti pronašla gotovo petina ispitanika, a na trgu prevladavajuće žute nijanse sadržavale su interpretacije nešto manje od desetine posjetitelja.

Dosad je moguće dati nekoliko općih opaski. Prije svega, pokazalo se kako predodžbe više od četiri petine $(86,5 \%)$ posjetitelja Arena Centra ne koincidiraju s idejnim rje-

5 Osim u potpunosti ispravnog, priznati odgovori bili su: splitsko područje, Split, Dubrovnik, Jadran i more. Bez njih, udio ispitanika koji su uspostavili asocijaciju s Dalmacijom iznosio bi tek 6,6 \%. Time bi prostor trga Dalmacija najveći udio ispitanika asocirao na Istru! Od četvorice ispitanika koji dolaze iz Dalmacije, tek je jedan odgovorio da ga trg svojim obilježjima podsjeća na tu regiju, no u kasnijem je razgovoru priznao razlog takvoga izjašnjavanja: “Iz Splita sam, pa neka bude!” (Anketno istraživanje).

6 Osim ispravnog, priznati su odgovori: Pula i arena u Puli. I bez njih bi udio asocijacija koje se poklapaju s idejnim rješenjem gradnje bio najviši od svih trgova u Arena Centru, a iznosio bi 16,0 \%. Tek su dvojica ispitanika anketiranih na području tog trga Istrani, a jednoga je od njih spomenuti prostor uistinu asocirao na regiju iz koje dolazi (Anketno istraživanje).

7 U obzir je uzet i odgovor kontinentalna Hrvatska. Bez njega bi se udio Slavonije spustio na 10,9 \%, što ne predstavlja značajniju razliku. Petorica ispitanika anketiranih na trgu Slavonija bili su Slavonci. Od njih je samo jednog taj prostor asocirao na Slavoniju (Anketno istraživanje). 
šenjem gradnje (tablica 2.). Uporabom odabranih motiva (jarboli jedrenjaka, pulska arena, žito) nisu pogođeni univerzalno razumljivi prostorni označitelji ili su, s drugog kuta gledišta, naprosto suviše apstraktno izneseni. Nije isključeno ni da su univerzalni obrasci potrošnje nadvladali arhitektonska rješenja, iako su ona nastojala u obzir uzeti lokalne povijesne i geografske uvjete (Laviolette, 2012.), kao ni da trgovi Arena Centra ne uspijevaju označiti baš ništa jer su preopterećeni značenjem (Lefebvre, 1991.). Nadalje, s obzirom na uvriježeno i stereotipizirano mišljenje da muški rod ima razvijeniju prostornu imaginaciju, jedan od zadataka ovog dijela rada bio je ispitati povezanost između rodnog izjašnjavanja i prostornih predodžbi. Rezultati istraživanja oprečni su toj pretpostavci (tablica 2.). Iako se pokazalo da žene imaju razvijeniju prostornu imaginaciju, rezultati hi-kvadrat testa $\left(\chi^{2}=0,497 ; \mathrm{df}=1 ; \mathrm{p}<0,05\right)$ sugeriraju da prostorna imaginacija nije statistički značajno rodno uvjetovana.

Tablica 2.

Ispitanici čija percepcija trgova odgovara idejnom rješenju gradnje

\begin{tabular}{|l|c|c|c|c|c|c|c|c|c|c|c|c|}
\hline \multirow{2}{*}{ Rod } & \multicolumn{3}{|c|}{ Dalmacija } & \multicolumn{4}{|c|}{ Istra } & \multicolumn{3}{c|}{ Slavonija } & \multicolumn{3}{c|}{ Ukupno } \\
\cline { 2 - 15 } & Da & Svi & $\%$ & Da & Svi & $\%$ & Da & Svi & $\%$ & Da & Svi & $\%$ \\
\hline Muški & 4 & 55 & 7,3 & 11 & 51 & 21,6 & 4 & 52 & 7,7 & 19 & 158 & 12,0 \\
\hline Ženski & 9 & 66 & 13,6 & 12 & 80 & 15,0 & 10 & 67 & 14,9 & 31 & 213 & 14,6 \\
\hline Ukupno & 13 & 121 & 10,7 & 23 & 131 & 17,6 & 14 & 119 & 11,8 & 50 & 371 & 13,5 \\
\hline
\end{tabular}

Izvor: Anketno istraživanje.

Možemo ustvrditi da se tema trgovačkog centra u svojoj punini ne uspijeva realizirati. Međutim, u tom se neuspjehu krije potencijalni ključ budućeg razvitka. Naime, poznato je da se ljudi kreću potrošačkim prostorom potaknuti konstrukcijom narativa koji se ostvaruje hodanjem (Goss, 1993.), kao i da "na hodanje potiču preostaci značenja i ponekad njihovi otpaci” (De Certeau, 2002.:170). Jedna posjetiteljica, koja nije bila svjesna teme centra ni njegove podijeljenosti na regije, ustvrdila je kako "bi bilo zanimljivije šetati centrom” znajući da trgovi predstavljaju specifične dijelove $\mathrm{Hr}$ vatske (Anketno istraživanje). Mogućnosti koje otvara bolje komuniciranje te ideje predstavljaju potencijalno važan element za ostvarivanje poslovnog rasta.

Prostor bilo kojeg trga Arena Centra, ali ponajviše Slavonije, percipiran je kroz njemu svojstvene i stoga determinirajuće prakse, koje "artikuliraju [specifično] prostorno iskustvo" te od njega stvaraju jedinstvenu "polivalentnu" cjelinu (De Certeau, 2002.:183). Trgovi su mjesta okupljanja. Žarišta svakog od njih predstavljaju ugostiteljski objekti. Pritom su kafići karakteristično obilježje bilo koje hrvatske regije. S druge strane, ručati na trgu Slavonija, uz malo vjerojatnu predodžbu da se posjetitelj nalazi u toj hrvatskoj regiji, znači doživjeti gastronomsko iskustvo iz potencijalno različitih dijelova svijeta, uz istovremenu imaginaciju prostorne drugosti, tj. onog što je Goss (1993.) nazvala sense of elsewhere. Stoga Slavonija ima najizraženija obilježja 
nemjesta. Međutim, globaliziranost gastronomske ponude, koja odgovara stanju Augéovskog supermoderniteta (prije svega prostorno i vremensko preobilje) nije jedini čimbenik na osnovi kojeg to možemo tvrditi. Naime, Slavonija je smještena na glavnom ulazu u centar, pa ju karakterizira najveći protok ljudi u jedinici vremena, tj. najviši stupanj tranzitnosti i dinamike. Prema tomu, i temeljna obilježja rekonceptualiziranog poimanja nemjesta ovdje najviše dolaze do izražaja.

\subsection{Odnos posjetitelja prema prostorno-vremenskoj realnosti}

Kako bismo odredili prirodu odnosa posjetitelja trgovačkog centra s izvanjskom prostorno-vremenskom realnošću, oslanjamo se na dvije komponente. Prva se tiče gubljenja sposobnosti opažanja protoka vremena u temporalnom smislu, a druga nepostojanja svijesti o aktualnim vremenskim prilikama. Slabije poimanje protoka vremena ispitano je uz pomoć tvrdnje - "Prilikom boravka u Arena centru vrijeme mi naprosto proleti” - koju su ispitanici vrednovali pomoću Lickertove skale (od 1 - Uopće se ne slažem do 5 - U potpunosti se slažem). Dobiveni prosječan odgovor iznosi 3,62 (kod muškaraca 3,26, a kod žena 3,89). Nadalje, valja istaknuti da je gubitak osjećaja za protok vremena usko povezan $s$ trajanjem boravka u trgovačkom centru (slika 1.), pri čemu ta veza nije naročito jaka, no statistički je značajna $(\mathrm{p}=0,001 ; \mathrm{r}=0,142)$. Time je potvrđeno da ekonomski determiniran prostor sebi subordinira vrijeme (Lefebvre, 1991.). To se očitava i kroz mogućnosti koje pruža idejno rješenje gradnje centra, bilo da se radi o prostorno-vremenskoj konvergenciji koja skraćuje vrijeme potrebno da se dođe od jedne do druge hrvatske regije, bilo da je riječ o putovanju kroz vrijeme. Naime, percepcija pulskog amfiteatra, osim što posjetitelja vodi na imaginarno prostorno putovanje, istovremeno mu otvara vrata antike.

Slika 1.

Poimanje protoka vremena s obzirom na trajanje boravka posjetitelja u Arena centru

\section{Lickertova \\ skala}

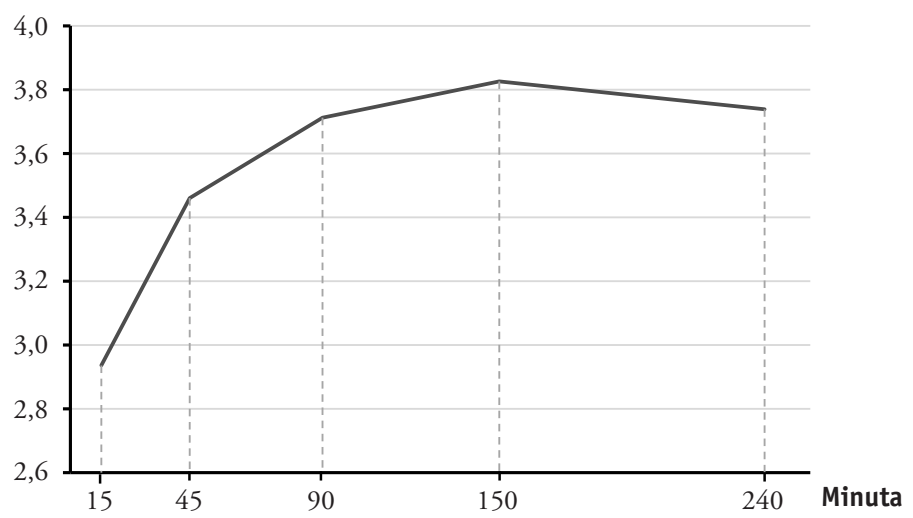

Izvor: Anketno istraživanje. 
Tijekom drugog dana provođenja anketnog istraživanja primijećeno je da dio ispitanika na pitanje "Kakvo je vani vrijeme?" odgovara tek nakon što podigne pogled prema prozorima. Stoga je navedeno pitanje eliminirano u svom izvornom obliku, a posljednjeg dana anketiranja odlučeno je promatrati, bilježiti i brojati ispitanike koji kod tog pitanja dignu pogled. ${ }^{8}$ Od ukupno 182 ispitanih, to je ponašanje zapaženo kod njih 37,4 \%. Međutim, to ne znači opovrgavanje teze o nestajanju veze posjetitelja trgovačkog centra s eksternom prostorno-vremenskom realnošću. Štoviše, budući da su pogled češće dizali posjetitelji koji duže borave u centru $(\mathrm{p}<0,001 ; \mathrm{r}=0,304)$, valjalo je prema jednadžbi odgovarajućeg pravca izračunati udio posjetitelja koji u centru boravi (u subotu) prosječnih 132,5 minuta, tj. medijalnih 105 minuta, a koji nisu u mogućnosti bez dizanja pogleda odgovoriti na postavljeno pitanje. S obzirom na to da je dobivenim udjelima ostvarena natpolovična većina, prihvatit ćemo početnu hipotezu te ustvrditi kako zatvorenost prostora, umjetno osvjetljenje i ostali specifični faktori interijera onemogućuju percepciju i/ili dosjećanje izvanjskih vremenskih prilika. Osim toga, valja zaključiti kako se odmak od izvanjskog prostorno-vremenskog realiteta pokazuje to značajnijim s porastom trajanja boravka posjetitelja u trgovačkom centru.

\subsection{Društveno prizorište, potrošačke prakse i prostorna dinamika}

Posve očekivano, kupovina je najučestalija praksa u trgovačkom centru. Više od dvije trećine posjetitelja kupuje, uz što je najuže povezano razgledavanje $(53,6 \%)$. Nešto više od trećine posjetitelja posjećuje ugostiteljske objekte. Četvrtina koristi trgovački centar kao prostor za rekreaciju (šetanje), 18,6 \% kao mjesto druženja s prijateljima i/ ili obitelji, dok 9,4\% odlazi u kino (Anketno istraživanje). Taj udio koincidira s pretpostavljenim udjelom površine multipleksa u ukupnoj površini Arena Centra.

Kod posjetitelja koji šeću, razgledavaju, kupuju, posjećuju ugostiteljske objekte ili provode vrijeme družeći se detektirani su poprilični kontrasti u zastupljenosti obavljanja ostalih praksi. Međutim, kod posjetitelja koji odlaze u kino ne postoji statistički značajna razlika u zastupljenosti obavljanja ostalih aktivnosti $\left(\chi^{2}=0,515\right.$; $\mathrm{df}=4$; $\mathrm{p}<$ $0,05)$. Stoga se lociranje multipleksa u trgovački centar pokazuje najboljim načinom podizanja dinamike svih ostalih (ispitivanih) potrošačkih praksi.

Hi-kvadrat testom provjerili smo vezu između praksi koje posjetitelji obavljaju u centru i spola, odnosno dobnih skupina (tablica 3.). Za razliku od raširenog mišljenja

${ }^{8}$ Već pri odgovaranju na prvo pitanje ispitanici su nužno morali dignuti pogled s ciljem promatranja čitavog prostora trga na kojem su ispitivani i kako bi pokušali povezati njegova prostorna obilježja s nekom hrvatskom regijom. Stoga je brojka koju ovdje bilježimo zapravo drugo dizanje pogleda, odnosno valja pretpostaviti da bi realan udio posjetitelja centra koji nije u mogućnosti procijeniti kakve su vremenske prilike izvan centra trebao biti znatno veći od dobivenog. 
da postoje znatne razlike prema spolu kad je riječ o kupovanju, pokazalo se upravo suprotno. Isti je slučaj s praksom druženja. Kad je riječ o dobi, jedina aktivnost koja se statistički značajno ne razlikuje s obzirom na starost ispitanika tiče se posjete ugostiteljskim objektima. Zanimljivo je istaknuti i dobne skupine koje su najučestaliji kupci u Arena Centru. Riječ je o posjetiteljima starosti između 25 i 29 (77,4 \%), tj. 30 i 39 godina $(74,4 \%)$. Istovremeno, najstarija dobna skupina (50 i više) najrjeđe navodi kupovinu kao razlog posjete Arena Centru.

Tablica 3.

Rezultati $\chi^{2}$-testa između aktivnosti i spola/dobi posjetitelja

\begin{tabular}{|l|c|c|c|c|c|c|}
\hline & \multicolumn{3}{|c|}{ Spol } & \multicolumn{3}{c|}{ Dobne skupine } \\
\hline Aktivnost & $\chi^{2}$ & $\mathrm{df}$ & $\mathrm{P}$ & $\chi^{2}$ & $\mathrm{df}$ & $\mathrm{P}$ \\
\hline Šetanje centrom & 0,411 & 1 & 0,521 & 9,536 & 5 & 0,089 \\
\hline Razgledavanje & 1,714 & 1 & 0,190 & 8,165 & 5 & 0,147 \\
\hline Kupovanje & 6,075 & 1 & 0,014 & 3,150 & 5 & 0,677 \\
\hline Odlazak u kino & 0,085 & 1 & 0,771 & 2,184 & 5 & 0,823 \\
\hline Ugostiteljski objekti & 0,519 & 1 & 0,471 & 15,751 & 5 & 0,008 \\
\hline Druženje & 10,855 & 1 & 0,001 & 10,757 & 5 & 0,056 \\
\hline
\end{tabular}

Izvor: Anketno istraživanje.

Trgovački centar pokazuje se izuzetno važnim prostorom socijalne interakcije i rekreacijskih aktivnosti stanovništva treće životne dobi. Pritom su rezultati istraživanja pokazali da su upravo umirovljenici ona skupina posjetitelja Arena Centra koja najveći udio vremena provodi družeći se $(37,5 \%)$ i šetajući centrom $(62,5 \%)$.

Nekoliko važnih opaski proizlazi iz odnosa pojedine aktivnosti i načina dolaska u trgovački centar. Razumno je tvrditi da posjetitelji koji dolaze pješice žive najbliže Arena Centru. Upravo je u toj skupini razmjerno najveći udio ljudi koji odlazi u kino (17,7 $\%$, provodi vrijeme družeći se $(35,3 \%)$ ili posjećujući ugostiteljske objekte $(58,8$ $\%)$. Te su informacije neobično važne budući da, nakon Avenue Malla, Arena Centar dodatno pridonosi brisanju oznake spavaonice s Novoga Zagreba, koji svojem stanovništvu, izuzev stanovanja, nije nudio dodatne urbane sadržaje. Uz to, predstavljaju izuzetno važan obrat u odnosu na ranija istraživanja (npr. Jakovčić i Spevec, 2004.), koja su isticala da se zagrebački suburbani trgovački centri, zbog prevage trgovinskih funkcija, ne percipiraju kao mjesta provođenja slobodnog vremena.

${ }^{9} \mathrm{~S}$ obzirom na to da je u ukupnom uzorku bilo tek osmero umirovljenika, iznesene brojke valja uzeti s oprezom. 
Ispitivanjem odnosa dinamike potrošačkih praksi s obzirom na dan u tjednu ili doba dana te trajanje posjeta pokazalo se da broj aktivnosti zavisi o dijelu tjedna $\left(\chi^{2}=\right.$ $15,873 ; \mathrm{df}=12 ; \mathrm{p}=0,197)$, odnosno dijelu dana $\left(\chi^{2}=13,737 ; \mathrm{df}=12 ; \mathrm{p}=0,318\right) \mathrm{u}$ kojem posjetitelj boravi u trgovačkom centru (Anketno istraživanje). Također, pojava gotovo svake ispitivane potrošačke prakse ovisna je o danu u tjednu u kojem posjetitelj dolazi u centar, uz izuzetak razgledavanja, odnosno o dijelu dana, pri čemu izuzetak predstavljaju kupovina i posjeta ugostiteljskim objektima (tablica 4.). Time smo dokazali da se u trgovačkom centru odvija dinamika različitih potrošačkih aktivnosti. Ovisno o tome koja praksa preteže, (re)konstruira se i karakter trgovačkog prostora, pri čemu je jasno - i to valja naglasiti - da Arena Centar nije isključivo mjesto kupovine, već i provođenja slobodnog vremena (druženje), rekreacije (šetanje) i zabave (odlazak u kino).

Tablica 4.

Rezultati $\chi^{2}$-testa između specifičnih aktivnosti i dijela tjedna, odnosno doba dana

\begin{tabular}{|l|c|c|c|c|c|c|}
\hline & \multicolumn{3}{|c|}{ Dan u tjednu } & \multicolumn{3}{c|}{ Dio dana } \\
\hline Aktivnost & $\chi^{2}$ & $\mathrm{df}$ & $\mathrm{P}$ & $\chi^{2}$ & $\mathrm{df}$ & $\mathrm{P}$ \\
\hline Štanje centrom & 0,520 & 2 & 0,771 & 5,602 & 2 & 0,061 \\
\hline Razgledavanje & 6,998 & 2 & 0,030 & 1,151 & 2 & 0,562 \\
\hline Kupovanje & 3,384 & 2 & 0,184 & 9,573 & 2 & 0,008 \\
\hline Odlazak u kino & 2,540 & 2 & 0,281 & 4,560 & 2 & 0,102 \\
\hline Ugostiteljski objekti & 4,734 & 2 & 0,094 & 6,303 & 2 & 0,043 \\
\hline Druženje & 1,005 & 2 & 0,605 & 2,180 & 2 & 0,336 \\
\hline
\end{tabular}

Izvor: Anketno istraživanje.

Iako jakost veze nije velika, statistički je značajan rezultat korelacije između trajanja boravka u centru i broja obavljenih aktivnosti $(\mathrm{p}=0,001 ; \mathrm{r}=0,136)$. Osim toga, broj aktivnosti koje posjetitelji obavljaju raste do približno dva i pol sata provedena u centru, nakon čega pravac mijenja smjer, čime je potvrđena još jedna od inicijalno postavljenih pretpostavki.

Ne samo da se broj aktivnosti mijenja s vremenom provedenim u centru, već trajanje boravka ovisi upravo o specifičnoj praksi koju posjetitelj obavlja. Tako je prosječan boravak posjetitelja koji posjećuju ugostiteljske objekte 16,8 minuta duži od uobičajenog. Time su potvrđena ranija istraživanja prema kojima posjeta prostoru gdje su koncentrirani restorani brze hrane (engl. food court) produljuje prosječno trajanje boravka za barem 10 - 15 minuta (Goss, 1993.). Uz to, aktivnosti koje produljuju boravak u trgovačkom centru su: kupovina, odlazak u kino i druženje s prijateljima i/ili obitelji. $S$ druge strane, šetanje i razgledavanje znače prosječno kraće zadržavanje u centru. 
Razmotrit ćemo i kvantitativno-kvalitativni međuodnos potrošačkih aktivnosti. Kod ispitanika koji su obavljali samo jednu aktivnost najviše je njih kupovalo, zatim razgledavalo te šetalo centrom. Poredak se djelomično mijenja već kod posjetitelja koji su kombinirali dvije, tj. tri simultane prakse. Naime, šetanje je ustupilo mjesto odlasku u ugostiteljske objekte. Daljnjim porastom broja aktivnosti kompozicija praksi u potpunosti se mijenja. Najveći udio posjetitelja koji su obavljali četiri različite prakse posjećivao je ugostiteljske objekte, slijedi aktivnost razgledavanja, a kupovina je pala na treće mjesto. Pritom su razlike između navedenih aktivnosti manje nego u ranijim slučajevima. Kod pet obavljenih aktivnosti, uz prethodno spomenute, svi su posjetitelji naveli druženje s prijateljima i/ili obitelji, njih preko dvije trećine šetanje, a trećina odlazak u kino. Time je pružen uvid u dinamiku koja nastaje samo na osnovu odabira broja i oblika aktivnosti.

\section{Zaključak}

Vodeći se Lefebvreovom (1991.) tezom da svako društvo proizvodi svoj vlastiti urbani prostor te zahtjevom da bi discipline koje se bave prostorom morale moći reproducirati i izložiti proces njegova nastanka, osmišljen je i operacionaliziran interpretativni model analize prostora trgovačkog centra i njegovog urbaniteta. Postavljene su četiri polazišne pretpostavke, čijim je testiranjem provjereno funkcioniranje osmišljenog interpretativnog modela na konkretnom primjeru Arena Centra.

Prva hipoteza glasila je da se predodžbe posjetitelja Arena Centra o tom trgovinskom prostoru ne podudaraju s idejnim rješenjem gradnje. $S$ obzirom na to da percepcije više od četiri petine ispitanika ne koincidiraju s osmišljenom arhitektonskom idejom, hipoteza je potvrđena. Pritom se očitim pokazalo nekoliko činjenica. Prvo, uporabom odabranih reprezentacijskih motiva Istre, Slavonije i Dalmacije nisu pogođeni univerzalno razumljivi prostorni označitelji. $\mathrm{K}$ tome, ti su motivi prosječnom posjetitelju centra suviše apstraktno izvedeni. Nije isključena ni mogućnost da su univerzalni obrasci potrošnje naprosto nadvladali arhitektonska rješenja, iako su ona nastojala u obzir uzeti lokalne historijsko-geografske datosti (Laviolette, 2012.), kao ni da trgovi Arena Centra ne uspijevaju označiti baš ništa uslijed prostornog preobilja (Augé, 2001.) i preopterećenosti značenjem (Lefebvre, 1991.).

Drugom se hipotezom provjeravalo gubljenje pojma o vremenu (u temporalnom smislu) te percepcije izvanjskih vremenskih prilika (u meteorološkom značenju) u ovisnosti o trajanju boravka u trgovačkom centru. Budući da je detektirana statistički značajna povezanost između gubljenja pojma o vremenu i trajanja boravka u trgovačkom centru, prva sastavnica druge hipoteze je potvrđena. Uz to, nemogućnost zamjećivanja temporalnosti povećava se do dva i pol sata provedena u centru, da bi se zatim trend počeo postepeno mijenjati. Time je potkrijepljena teza da ekonomski determiniran prostor sebi subordinira vrijeme (Lefebvre, 1991.). Ona se očitava kroz mogućnosti 
koje pružaju tematska obilježja Arena centra, bilo da se radi o prostorno-vremenskoj konvergenciji koja skraćuje vrijeme potrebno da se dođe od jedne do druge hrvatske regije, bilo da je riječ o upravljanju vremenom koje se ostvaruje putovanjem kroz temporalno. Drugi element hipoteze ticao se mogućnosti prisjećanja aktualnih vremenskih prilika. Kako bi odgovorili na pitanje kakvo je vani vrijeme, češće su pogled prema prozorima dizali posjetitelji koji duže borave u centru. Pritom je to ponašanje primijećeno kod više od polovice ispitanika, uzimajući u obzir bilo prosječno bilo medijalno trajanje boravka u centru. Stoga valja u cijelosti prihvatiti drugu hipotezu te konstatirati kako zatvorenost prostora, umjetno osvjetljenje i ostali specifični čimbenici stvaraju odmak od izvanjskih prostorno-vremenskih uvjeta.

Kontinuirano stvaranje trgovinskog prostora kroz koloplet raznorodnih potrošačkih praksi te njihova nejednaka konstelacija s obzirom na dio tjedna i doba dana činili su bazu treće hipoteze. Kupovina je najučestalija potrošačka aktivnost u Arena Centru. Uostalom, primarna je namjena postojanja svakog trgovačkog prostora upravo trgovinska razmjena. Međutim, Arena Centar nije isključivo trgovinski prostor. Budući da gotovo desetina svih ispitanika odlazi u kino, što korespondira s površinom zakupljenog prostora multipleksa u ukupnoj površini centra, Arena Centar je i prostor zabave. Pritom je važno napomenuti da kod posjetitelja koji odlaze u kino ne postoji statistički značajna razlika u zastupljenosti obavljanja ostalih aktivnosti. Stoga se lociranje multipleksa u trgovački centar pokazuje najboljim načinom podizanja dinamike svih ostalih ispitivanih potrošačkih praksi. Nadalje, trgovački se centar pokazuje važnim prostorom socijalne interakcije, odnosno rekreacijskih aktivnosti. Te su prakse razmjerno najviše naglašene kad je riječ o posjetiteljima treće životne dobi. Osim toga, trgovački je centar mjesto posjete ugostiteljskim objektima za više od trećine ispitanika. Time je potvrđeno postojanje različitih prostornih praksi koje oblikuju potrošački prostor te je uočen obrat u odnosu na ranija istraživanja (Spevec i Jakovčić, 2004.), koja su isticala da se zagrebački suburbani trgovački centri, zbog prevage trgovinskih funkcija, ne percipiraju kao mjesta provođenja slobodnog vremena. Osim toga, potvrđeno je da broj aktivnosti zavisi o dijelu tjedna, odnosno dijelu dana u kojem posjetitelj boravi u trgovačkom centru. Također, pojava gotovo svake potrošačke prakse ovisna je o dijelu tjedna u kojem posjetitelj dolazi u centar, uz izuzetak razgledavanja, odnosno o dijelu dana, pri čemu izuzetak predstavlja kupovina i posjeta ugostiteljskim objektima. Time smo dokazali da se u trgovačkom centru odvija dinamika različitih potrošačkih aktivnosti. Ovisno o tomu koja praksa preteže, (re)konstruira se i karakter trgovačkog prostora, pri čemu je jasno - i to valja ponoviti - da Arena Centar nije isključivo mjesto kupovine, već i provođenja slobodnog vremena, rekreacije i zabave.

Prema posljednjoj hipotezi, broj i odnos potrošačkih praksi mijenja se s vremenom provedenim u trgovačkom centru. Prvo, broj aktivnosti koje posjetitelji obavljaju raste $s$ trajanjem boravka u centru. Međutim, to vrijedi samo do oko dva i pol sata provedena u centru, nakon čega se broj obavljenih aktivnosti smanjuje. Ne samo da se broj 
aktivnosti mijenja s vremenom provedenim u centru, već trajanje boravka ovisi upravo o specifičnoj praksi koju posjetitelj centra (ne) obavlja. Nadalje, koloplet aktivnosti koje posjetitelji obavljaju ovisan je o vremenu provedenom u centru, no još više o broju obavljenih aktivnosti. To znači da će nakon već spomenutih dva i pol sata provedenih u centru sve manji udio posjetitelja razgledavati i posjećivati ugostiteljske objekte. Istovremeno, nastavlja rasti udio posjetitelja koji provode vrijeme družeći se, šetajući ili gledajući film u multipleksu. Još je zanimljivije razmotriti kvalitativno-kvantitativni međuodnos potrošačkih aktivnosti. Obavlja li posjetitelj samo jednu aktivnost, najvjerojatnije je da će kupovati. Povećanjem broja aktivnosti u mnogo većoj mjeri raste vjerojatnost odabira drugih ispitivanih potrošačkih praksi. Primjerice, kod posjetitelja koji su obavljali četiri aktivnosti najveći ih je udio odlazio u ugostiteljske objekte, zatim razgledavao, dok je kupovina pala na treće mjesto. Uvidom u dinamiku koja nastaje samo na osnovi odabira broja i oblika aktivnosti, detektirana je fluidnost i nestabilnost praksi, koja je rezultat isključivo njihovog unutrašnjeg modusa djelovanja.

Primjena osmišljenog konceptualnog modela omogućila je ne samo interpretativnu analizu konstruiranja prostora trgovačkog centra već i aplikativnost s više aspekata. Prvo, obilježja koje su posjetitelji učitavali u prostor trgova Arena Centra kako bi pokušali protumačiti njihova imena mogu poslužiti kao smjernice za njihovo (dodatno) brendiranje. Istovremeno, neuspjeh u ostvarivanju teme centra otvara prostor za njezinu bolju komunikaciju, čime bi se povećala cirkulacija ljudi u centru, ali i porastao broj posjetitelja. Podatak da starija populacija koristi trgovački centar u rekreacijske svrhe može biti putokaz u osmišljavanju dodatne ponude, a informacija da lociranje kina u potrošački prostor znači ravnomjernu intenzifikaciju svih ostalih aktivnosti, kao i mnogi drugi izneseni rezultati, mogu biti aplikativni kako za Arenu, tako i za bilo koji drugi trgovački centar.

\section{Literatura}

1. Anić, I. D.; Dlačić, J. i Jelenc, L. (2016). Odrednice kompulzivne kupnje: slučaj trgovačkog centra u Hrvatskoj. Privredna kretanja i ekonomska politika, 25 (1): 7-35.

2. Arias, S. (2008). The geopolitics of historiography from Europe to the Americas, in: Warf, B. and Arias, S. (Eds.). The Spatial Turn. Interdisciplinary Perspectives. London: Routledge.

3. Augé, M. (2001). Nemjesta: Uvod u moguću antropologiju supermoderniteta. Karlovac: Naklada Društva arhitekata, građevinara i geodeta.

4. Clarke, D. (2006). Postmodern Geographies and the Ruins of Modernity, in: Aitken, S. and Valentine, G. (Eds.). Approaches to Human Geography. London: Sage Publications.

5. Coleman, P. (2006). Shopping Environments. Evolution, Planning and Design. Oxford: Elsevier. 
6. Crewe, L. (2000). Geographies of retailing and consumption. Progress in $\mathrm{Hu}$ man Geography, 24 (2): 275-290.

7. De Certeau, M. (2002). Invecnija svakodnevice. Zagreb: Naklada MD.

8. Foucault, M. (1997). Of Other Spaces: Utopias and Heterotopias, in: Leach, N. (Ed.). Rethinking Architecture: A Reader in Cultural Theory. New York: Routledge.

9. Goss, J. (1993). The Magic of the Mall: An Analysis of Form, Function, and Meaning in the Contemporary Retail Built Environment. Annals of the Associattion of American Geographers, 83 (1): 18-47.

10. Gregory, D.; Johnston, R.; Pratt, G.; Watts, M.; Whatmore, S. (Eds.) (2009). The Dictionary of Human Geography. Chichester: Wiley-Blackwell.

11. Gregory, T. (2011). The Rise of the Productive Non-Place: The Contemporary Office as a State of Exception. Space and Culture, 14 (3): 244-258.

12. Hui, A. and Walker, G. (2018). Concepts and methodologies for a new relational geography of energy demand: Social practices, doing-places and settings. Energy Research \& Social Science, 36: 21-29.

13. Jakovčić, M. (2011). Geografija slobodnog vremena mladih - kako izabrati svoj najdraži trgovački centar. Hrvatski geografski glasnik, 73 (1): 51-69.

14. Jakovčić, M. i Rendulić, I. (2008). Razvoj i funkcije kupovnih centara u Zadru. Geoadria, 13 (1): 97-117.

15. Jakovčić, M. i Spevec, D. (2004). Trgovački centri u Zagrebu. Hrvatski geografski glasnik, 66 (1): 47-66.

16. Jones, A. and Murphy, J. (2011). Theorizing practice in economic geography: Foundations, challenges, and possibilities. Progress in Human Geography, 35 (3): 366-392.

17. Laviolette, P. (2012). Non-Places of non-Augé, Material world: A global hub for thinking about things. http://www.materialworldblog.com/2012/11/non-placesof-non-augel. (Pregledano 22. studenog 2018.)

18. Lefebvre, H. (1991). The Production of Space. Oxford: Blackwell.

19. Lourenco, J. and Bardi, T. (2007). Shopping Areas and Strategic Planning Congress Report. 43rd ISOCARP Congress: Urban Trialogues. http://www.isocarp.net/. (Pregledano 23. travnja 2019.)

20. Lukić, A. (2002). Socijalne funkcije trgovačko-poslovnog središsta: Primjer Centra Kaptol u Zagrebu. Hrvatski geografski glasnik, 64 (1): 73-94.

21. Lukić, A. and Jakovčić, M. (2004). Location and function of hypermarkets and shopping centers in Zagreb. Dela, 22: 39-54.

22. Mak, K.; Dumić, V. i Jakovčić, M. (2017). Geografija potrošnje mladih: Usporedba potrošačkih navika maturanata iz Samobora i Zaboka. Godišnjak grada Zaboka, 4: 212-230.

23. Mak, K. i Knežević, F. (2017). Slabljenje centralnih funkcija ruralnog prostora: Studija slučaja Sveti Križ Začretje. Geografski horizont, 63: 43-53.

24. Makgopa, S. (2016). Determining shopping mall visitors' perceptions on mall attributes. Problems and Perspectives in Management, 14 (39): 522-527. 
25. Menatti, L. (2011). From Non-Place to Rhizome: A Geophilosophical Analysis of Contemporary Globalized Space. Environment, Space, Place, 3 (2): 22-50.

26. Merriman, P. (2004). Driving Places: Marc Augé, Non-places, and the Geographies of England's M1 Motorway. Theory, Culture \& Society, 21 (4/5): 145-167.

27. Nodilo, B. (2010). Arena centar: Novo trgovačko-zabavišno središte u Zagrebu. Gradevinar, 62 (8): 731-741.

28. Sibley, D.; Jackson, P.; Atkinson, D.; Washbourne, N. (Eds.) (2005). Cultural Geography. A Critical Dictionary of Key Concepts. London-New York: I. B. Tauris.

29. Schatzki, T. (2002). The Site of the Social: A Philosophical Account of the Constitution of Social Life and Change. University Park: Pennsylvania State University Press.

30. Soja, E. (2008). Taking Space Personally, in: Warf, B. and Arias, S. (Eds.). The Spatial Turn. Interdisciplinary Perspectives. London: Routledge.

31. Stanić, S. (2009). Socijalni kontekst trgovačkog centra. Zbornik radova Filozofskog fakulteta u Splitu, 2/3: 135-151.

32. Szczuraszek, T. and Karwasz, M. (2018). Transport attractiveness of shopping malls. Tehnical transactions, 7: 101-112.

33. Šakaja, L. (2015). Uvod u kulturnu geografiju. Zagreb: Leykam International.

34. Tomlinson, J. (1999). Globalization and culture. Chicago: The University of Chicago Press.

35. Tonković, Ž. (2015a). Trgovački centri i promjene u gradskoj jezgri: Slučaj Zadra. Sociologija i prostor, 53 (1): 3-20.

36. Tonković, Ž. (2015b). Hedonisti i utilitaristi: tipovi posjetitelja trgovačkog centra Supernova Zadar. Sociologija i prostor, 53 (3): 193-212.

37. Ursić, S., 2009: Mjesta i nemjesta u suvremenim konceptualizacijama prostora. Društvena istraživanja, 18 (6): 1131-1151.

38. Varnelis, K. (2010). Globalization and Non-place. http://index.varnelis.net/network culture/globalization and nonplace. (Pregledano 11. studenog 2018.)

39. Warde, A. (2005). Consumption and Theories of Practice. Journal of Consumer Culture, 5 (2): 131-153.

40. Warf, B. and Arias, S. (2008). Introduction: The reinsertion of space in the humanities and social sciences, in: Warf, B. and Arias, S. (Eds.). The Spatial Turn. Interdisciplinary Perspectives. London: Routledge.

41. Woodward, I. (1998). The shopping mall, postmodern space and architectural practice: Theorising the postmodern spatial turn through the planning discourse of mall architects. Architectural Theory Review, 3 (2): 45-56.

42. Zlatar, J. (2011). Utjecaj trgovačkih centara (kao nemjesta) u Zagrebu na nestajanje javnog prostora, u: Čapo, J. i Gulin Zrnić, V. (Ur.). Mjesto, nemjesto - Interdisciplinarna promišljanja prostora $i$ culture. Zagreb: Institut za etnologiju i folkloristiku. 


\section{Izvori}

1. Arena centar (2017). B2B brošura, Pregledano 14. travnja 2019. (https://www.arenacentar.hr/wp-content/uploads/ B2B.pdf).

2. Arena centar (2019). Trgovine, Mapa centra, Pregledano 27. travnja 2019. (https:// www.arenacentar.hr/).

3. Ciglar, D. i Opalić, Z. (2010). Welcome to Zagreb City. Novi puls grada. Pregledano 30. travnja 2019. (https://upi-2m.hr/made-in-arena/).

4. CineStar (2019). CineStar Arena Zagreb. Pregledano 23. travnja 2019. (https://www. blitz-cinestar.hr/). 


\title{
Geography of Non-place: An Analysis of the Arena Centar in Zagreb (Microlevel)
}

\author{
Karlo Mak \\ Antun Gustav Matoš Secondary School, Samobor, Croatia \\ e-mail:karlo.mak2@skole.hr \\ Martina Jakovčić \\ Faculty of Science of the University of Zagreb, Department of Geography, Croatia \\ e-mail:mjakovci@geog.pmf.hr
}

\begin{abstract}
Drawing on Augé's concept of non-place, an interpretative model for the analysis of the shopping mall has been constructed. The model is formed on two dialectically interlinked levels. For the analysis of the lower spatial level (the Arena Centar itself), the concept of non-place is fused with Schatzski's social site, while the macro-level analysis (of the residential area surrounding the Arena Centar) is based on transitional marks that visitors of the mall leave in space. This paper presents the results at a lower spatial level. The operationalisation of the present model led to the finding that, through spatial overabundance and excess of meaning, the conceptions of the mall's visitors do not match the original concept of the building. The analysis shows that the more time the visitors spend in the shopping mall, the more they lose touch with the external spatiotemporal reality. Finally, it has confirmed the existence of the dynamics of different social practices, which mould the space of the Arena Centar from solely a place of commercial into a place of leisure activities as well.
\end{abstract}

Key words: non-place, social site, shopping mall, Arena Centar. 